\title{
$\mathbb{E}] P][G] R A] P] H[E$ \\ (Jurnal Teologi dan Pelayanan Kristiani)
}

Volume 1, Nomor 2, November 2017 (73-90)

ISSN: 2579-9932 (online), 2614 - 7203 (print)

http://www.stttorsina.ac.id/jurnal/index.php/epigraphe

\section{Dukungan Terhadap Anggota Keluarga Lansia dalam Melayani}

\author{
Agustin Soewitomo Putri
}

Sekolah Tinggi Teologi Torsina Surkarta

tasoewitomo@gmail.com

Article History
Received:
November 2017
(printed)
Published:
November 2017
(printed)

Keywords: family; family's support; ministry; aged people
Kata kunci:

dukungan

keluarga;

keluarga; lansia;

pelayanan

\begin{abstract}
This research purposed to show the category level of family supported to the aged people in church ministry at Gereja Bethel Injil Sepenuh Kepunton, Surakarta, year 2016. Hypotheses of this research is: a category level of family's support to the aged people in church ministry is at Gereja Bethel Injil Sepenuh Kepunton, Surakarta, year 2016 is moderate. Analysis of correlation showed that family supported had a correlation level to the involvement of aged people in ministry is at 0.461, which means moderate. Though the hypotheses was tried and true, there were some recommendations to increase family supported to the aged people in ministry, like: making a seminar about family, special sermon's theme about family or special retreat for aged people.
\end{abstract}

\begin{abstract}
Abstrak
Penelitian ini bertujuan untuk mengetahui seberapa besar kategori dukungan keluarga terhadap keterlibatan jemaat lansia dalam melayani di Gereja Bethel Injil Sepenuh Kepunton Surakarta tahun 2016. Hipotesis penelitian adalah: tingkat kategori dukungan keluarga terhadap keterlibatan jemaat lansia dalam melayani di Gereja Bethel Injil Sepenuh Kepunton Surakarta tahun 2016 adalah sedang. Analisis korelasi membuktikan bahwa Dukungan Keluarga memiliki tingkat korelasi dengan Keterlibatan Jemaat Lansia Melayani sebesar 0,461 yakni pada tingkat korelasi yang sedang. Meskipun hipotesis terbukti, namun ada rekomendasi untuk meningkatkan dukungan keluarga terhadap anggota yang lansia untuk terlibat dalam melayani Tuhan, baik melalui seminr keluarga, tema khotbah tentang keluarga maupun retreat khusus lansia.
\end{abstract}




\section{Pendahuluan}

Keluarga, secara sederhana, merupakan kelompok masyarakat yang paling kecil. Biasanya konsep keluarga terkait pada sekelompok orang yang terdiri atas orang tua dan anak, yang tinggal dalam satu rumah. Menurut Marilyn M. Friedman kelearga adalah: "Kumpulan dua orang atau lebih yang hidup Bersama dengan keterikatan aturan dan emosinal dimana individu mempunyai peran masing-masing yang merupakan bagian dari keluarga."1 Friedman menekankan adanya sebuah ikatan dan komitmen atas ikatan tersebut. Setiap anggota dalam keluarga memiliki peran yang berbeda satu dengan yang lainnya. Peran tersebut terikat pada aturan yang telah dibuat sebelumnya, atau komitmen dalam pembentukan keluarga. Keluarga-keluarga di Indonesia memiliki ciri tersendiri, di mana nilai-nilai kebudayaan timur cukup kuat sehingga masing-masing keluarga biasanya ada ikatan yang jauh lebih erat dalam hubungan antara generasinya.

\section{Fungsi Keluarga}

Keluarga merupakan sebuah unit terkecil dalam masyarakat yang memiliki tujuannya sendiri. Tujuan tersebut merupakan tujuan yang hendak dicapai oleh setiap individu dalam keluarga. Dalam usaha untuk mencapai tujuan tersebut keluarga menjalankan peran sesuai fungsinya. Fungsi keluarga terbentuk oleh karena adanya interaksi, relasi dan interdependensi. Fungsi keluarga biasanya didefinisikan sebagai hasil atau konsekuensi dari struktur keluarga. Menurut Friedman fungsi keluarga secara umum dibagi menjadi lima fungsi ${ }^{2}$, yaitu fungsi afektif, sosialisasi, reproduksi, ekonomi dan fungsi perawatan atau pemeliharaan.

Fungsi afektif (the affective function) merupakan fungsi keluarga yang utama, yang berhubungan erat dengan fungsi internal keluarga. Ini merupakan basis kekuatan keluarga, karena berkaitan dengan setiap individu yang ada di dalam keluarga. Fungsi ini dibutuhkan untuk perkembangan individu dan psikososial anggota keluarga. Keberhasilan fungsi ini dapat terlihat pada pencapaian kebahagian dari seluruh anggota keluarga. Tiap anggota keluarga saling mempertahankan iklim yang positif dalam keluarga, perasaan memiliki, perasaan yang berarti dan merupakan sumber kasih sayang. Keluarga yang berhasil melaksanakan fungsi afektif ini juga ditandai dengan keberhasilan dari seluruh anggota keluarga untuk dapat mengembangkan konsep diri yang positif. Perceraian, kenakalan anak, pertikaian dalam rumah tangga dan

\footnotetext{
${ }^{1}$ Ferry Efendy dan Makhfudli, Keperawatan Kesehatan Komunitas: Teori dan Praktik dalam Keperawatan (Jakarta: Salemba Medika, 2009), 179.

${ }^{2}$ Ibid., 5
} 
persoalan-persoalan keluarga lainnya sering muncul akibat dari tidak terpenuhinya fungsi afektif dalam keluarga.

Dalam konteks Indonesia, fungsi keluarga dapat mengacu pada UU No.10 tahun 1992 jo PP No.21 tahun 1994, yaitu: fungsi keagamaan, budaya, cinta kasih, perlindungan, reproduksi, sosialisasi, ekonomi dan pelestarian lingkungan. ${ }^{3}$ Intinya, fungsi keluarga yang diuraikan hampir serupa dengan teori Friedman, hanya saja fungsi afektif diartikulasikan sebagai fungsi keagamaan dan kebudayaan. Manusia menyerap nilai-nilai keagamaan dan budaya menjadi dimensi afektif dalam dirinya.

Fungsi keagamaan yang dimaksud di sini adalah, bagaimana keluarga dapat membina norma ajaran-ajaran agama sebagai dasar dan tujuan hidup seluruh anggota keluarga, menerjemahkan agama ke dalam tingkah laku hidup sehari-hari kepada seluruh anggota keluarga, memberikan contoh konkrit dalam hidup sehari-hari dalam pengamalan dari ajaran agama, melengkapi dan menambah proses kegiatan belajar anak tentang keagamaan yang kurang diperolehnya di sekolah atau masyarakat, serta membina rasa, sikap, dan praktik kehidupan keluarga beragama sebagai pondasi menuju keluarga kecil bahagia sejahtera.

Sementara fungsi budaya adalah membina tugas-tugas keluarga sebagai lembaga untuk meneruskan norma-norma dan budaya masyarakat dan bangsa yang ingin dipertahankan. Keluarga menjadi bagian dari masyarakat kultur, sehingga nilai-nilai budaya tidak dapat diabaikan begitu saja. Persoalan budaya berkaitan dengan kearifan lokal di mana keluarga ada, bahkan pada bagian yang lebih besar berbicara tentang nilai kebangsaan. Moral keluarga harus mencerminkan nilai ideologi kebangsaan Indonesia yang tentu didukung oleh pranata budaya. Hal ini seperti yang diungkapkan oleh “...keluarga serta pranata keagamaan berperan sebagai pemelihara kehidupan moral."4

Melalui penjabaran fungsi-fungsi keluarga di atas, maka dapat disimpulkan bahwa keluarga adalah tempat pertama dan utama di mana seorang pribadi bertumbuh, berkembang, menerima pendidikan dan yang berikutnya dia akan menerima perlindungan baik secara ketenangan batin ataupun keagamaan dan terbangunnya ikatan antara pribadi yang akan terwujud hingga anggota keluarga tersebut memasuki fase lanjut usia.

${ }^{3}$ UU No.10 tahun 1992 jo PP No.21 tahun 1994

${ }^{4}$ T.O.Ihromi, Bunga Rampai Sosiologi Keluarga (Jakarta: Yayasan Obor, 1999), 16 


\section{Dukungan Keluarga}

Friedman berpendapat bahwa studi-studi tentang dukungan keluarga telah mengkonseptualisasi dukungan sosial, baik dukungan yang bersifat eksternal maupun internal terbukti sangat bermanfaat. "Dukungan keluarga eksternal antara lain sahabat, pekerjaan, tetangga, sekolah, keluarga besar, kelompok social, kelompok rekreasi, tempat ibadah dan praktisi kesehatan. Dukungan keluarga internal antara lain dukungan dari suami atau istri, dari saudara kandung atau dukungan dari anak."5 Berdasarkan pandangan tersebut maka keluarga menjadi tempat pertama bagi seorang individu untuk mendapatkan topangan ataupun dorongan dalam menghadapi berbagai proses.

Bagi seorang yang telah memasuki masa lanjut usia, berbagai perubahan yang dialami akan menimbulkan persoalan tersendiri yang terkadang akan dapat berpengaruh dalam kesehatan fisiknya ataupun keseimbangan mental psikologisnya. Tidak jarang karena perubahan-perubahan yang dialami oleh seorang lanjut usia juga akan berdampak kepada kerohaniannya. Karena kondisi inilah, maka keluarga menjadi tempat pertama bagi seorang lanjut usia untuk dapat memasuki proses penerimaan diri terhadap perubahan-perubahan kehidupan dan itulah sebabnya dukungan keluarga sangat dibutuhkan. "Dukungan keluarga merupakan bantuan yang dapat diberikan kepada keluarga lain berupa barang, jasa, informasi dan nasehat, yang mana membuat penerima dukungan akan merasa disayang, dihargai, dan tentram."6

Menurut Sarwono "dukungan adalah suatu upaya yang diberikan kepada orang lain, baik moril maupun materil untuk memotivasi orang tersebut dalam melaksanakan kegiatan." dukungan keluarga sangat erat hubungannya dengan salah satu fungsi dasar keluarga, yaitu fungsi afektif, di mana keluarga menjadi tempat untuk pemenuhan kebutuhan psikososial, saling mengasuh dan memberikan cinta kasih, serta saling menerima dan mendukung. "Menurut Friedman, dampak positif dari dukungan keluarga adalah meningkatkan penyesuaian diri seseorang terhadap kejadian-kejadian dalam kehidupan." 8

Gambaran dalam Perjanjian Lama tentang dukungan keluarga terhadap anggota keluarga dapat dilihat dalam kisah hidup beberapa tokoh di kitab Kejadian. Hal tersebut

\footnotetext{
${ }^{5}$ Harnilawati, Op.cit., 5

${ }^{6}$ http://griyaamerta-malang.blogspot.co.id/2014/12/dukungan-keluarga.html. Diunduh 24 Mei 2016; 20:25 WIB.

${ }^{7}$ Ibid.

${ }^{8}$ http://griyaamerta-malang.blogspot.co.id/2014/12/dukungan-keluarga.html. Diunduh 24 Mei 2016; 20:25 WIB.
} 
menjadi semakin menarik karena ternyata kegagalan dan keberhasilan mereka tidak dapat dilepaskan dari pengaruh dukungan keluarga, entah itu istri, suami, anak atau orang tua. Keberhasilan Nuh untuk menaati perintah Tuhan dengan membuat bahtera yang menjadi obyek cemoohan orang, tidak dapat dilepaskan dari faktor dukungan keluarga terhadap dia. Kegagalan Abraham dalam menanti janji Tuhan untuk lahirnya keturunan dari perkawinannya dengan Sara, tidak dapat dilepaskan dari pengaruh dukungan dari Sara sendiri. Keberhasilan Ishak mendapatkan istri yang baik juga tidak dapat dilepaskan dari dukungan keluarganya, termasuk Eliezer (hambanya yang paling tua, yang memegang kekuasaan atas seisi rumahnya).

Makna menghormati orang tua bukan hanya sekadar menggunakan ucapan dan bahasa tubuh yang penuh hormat terhadap orang tua serta menaati mereka dengan penuh sukacita dan kerelaan, tetapi juga menghormati mereka dengan subtansi yang ada, memenuhi kebutuhan mereka akan sandang, pangan dan kebutuhan hidup lain yang mereka butuhkan; yang dilakukan sebagai sebuah pelayanan seorang anak terhadap orang tuanya yang memang sudah sepantasnya mereka terima, sebagai balasan atas biaya dan perhatian yang telah mereka berikan serta berbagai masalah yang harus mereka hadapi tatkala orang tua membesarkan anak-anak mereka di dunia. Artinya, makna kata "hormatilah" memiliki pengertian yang bukan hanya berbicara tentang sikap ataupun tindakan seorang anak kepada orang tuanya pada saat orang tuanya masih kuat dan mampu menanggung hidup keluarga, terlebih lagi adalah pada saat orang tua sudah tidak lagi memiliki kekuatan seperti pada masa lampau.

Perintah untuk menghormati orang tua justru termasuk pada waktu kondisi orang tua sudah harus hidup bergantung kepada anak-anaknya. Menghormati orang tua melibatkan penghargaan, hormat dan dukungan. Itu berarti juga tanggungjawab untuk keluarga ada untuk mereka dan tetap memperhatikan mereka melalui pelayanan, dukungan, keuangan, kunjungan. Dengan demikian dalam teks "hormatilah ibu bapamu" terkandung makna bahwa bentuk penghormatan itu meliputi dukungan dalam segala segi, khususnya pada waktu orangtua telah memasuki masa usia lanjut dan tidak memiliki kekuatan fisik ataupun materi.

Dukungan keluarga dalam Perjanjian Baru berbicara pada dimensi pemeliharaan dengan semangat pengabdian. Ada hal yang menarik ketika mengamati dalam Perjanjian Baru, di mana perintah pemeliharaan terhadap orang tua atau nenek dituliskan oleh Paulus kepada Timotius, "Hormatilah janda-janda yang benar-benar 
janda. Tetapi jikalau seorang janda mempunyai anak atau cucu, hendaknya mereka itu pertama-tama belajar berbakti kepada kaum keluarganya sendiri dan membalas budi orang tua dan nenek mereka, karena itulah yang berkenan kepada Allah" (1 Timotius $5: 4,5)$

Dalam versi New English Tranlsation (NET) Bible, istilah honor dalam teks tersebut memiliki pengertian yang ganda, yakni: menghormati dan memberikan dukungan finansial. ${ }^{9}$ Kata "hormati” $(\tau \iota \mu \alpha \omega$, timao) memiliki pengertian: menghormati, memuliakan, penilaian. Menghormati; menetapkan harga (Mat 27.9); mengakui kedudukan, dan karena itu memberi bantuan uang (1Tim 5.13). ${ }^{10}$ Dengan demikian, pemakaian kata "hormatilah" memiliki makna adanya dukungan dari anak atau cucu yang dapat dalam bentuk dukungan financial ataupun dukungan sikap, dikenal dalam fungsi keluarga sebagai fungsi afektif . Ayat ini juga dengan jelas mengatakan bahwa anak cuculah yang seharusnya menjadi orang pertama yang wajib memperhatikan nasib mereka.

Dalam injil, Yesus juga menyinggung masalah dukungan terhadap orang tua yang telah lanjut usia, dengan memberikan sebuah teguran keras terhadap persoalan pemeliharaan terhadap orang tua. Markus 7:11-13, “Tetapi kamu berkata: Kalau seorang berkata kepada bapanya atau ibunya: Apa yang ada padaku, yang dapat digunakan untuk pemeliharaanmu, sudah digunakan untuk korban, yaitu persembahan kepada Allah, maka kamu tidak membiarkannya lagi berbuat sesuatupun untuk bapanya atau ibunya. Dengan demikian firman Allah kamu nyatakan tidak berlaku demi adat istiadat yang kamu ikuti itu. Dan banyak hal lain seperti itu yang kamu lakukan.

\section{Metodologi}

Metode dalam penelitian ini adalah analisis deskriptif dengan pendekatan kuantitatif. Penelitian diadakan di Gereja Bethel Injil Sepenuh Kepunton Surakarta, dengan populasi lansia 50 orang. Peneliti menggunakan instrumen angket untuk mencari dan mengumpulkan data sebagai bahan analisis dalam menemukan hasil penelitian. Sebelum data digunakan sebagai instrumen final dalam penelitian, penulis melakukan try out kepada 15 orang jemaat lansia, dan memperoleh hasil Iterasi Orthogonal dengan membuang sejumlah 14 item pernyataan yang tidak valid dari keseluruhan 65 butir item, sehingga tersisa 51 pernyataan.

\footnotetext{
${ }^{9}$ SABDA, CD-ROM
}

${ }^{10}$ Ibid. 
Uji persyaratan analisis mendapatkan nilai Asymp. Sig (2-tailed) variabel $\mathrm{X}=$ 0,173 dan Variabel $\mathrm{Y}=0,965$. Nilai tersebut di atas 0,05 seperti yang disyaratkan normal, sehingga angket terditribusi normal. Selanjutnya dalam penilaian Uji Linieritas didapatkan nilai sig. Linearity pada 0,017, di bawah 0,05 sesuai yang disyaratkan linear, sehingga data berpola linear. Penulis mengajukan hipotesis: Diduga dukungan keluarga terhadap keterlibatan jemaat lansia dalam melayani di Gereja Bethel Injil Sepenuh Kepunton Surakarta tahun 2016 ada pada kategori sedang

\section{Hasil dan Pembahasan}

Hasil dari perhitungan statistik dengan bantuan SPSS 17.0 for Windows, didapatkan sebagai berikut:

\section{Deskripsi Variabel Dukungan Keluarga}

Descriptive Statistics

\begin{tabular}{|l|c|c|c|c|c|c|}
\hline & $\mathrm{N}$ & Range & Minimum & Maximum & Mean & Std. Deviation \\
\hline DukunganKeluarga & 35 & 43 & 92 & 135 & 112.29 & 13.533 \\
\hline KeterlibatanMelayani & 35 & 37 & 73 & 110 & 92.57 & 10.584 \\
\hline Valid N (listwise) & 35 & & & & & \\
\hline
\end{tabular}

Berdasarkan tabel di atas, batas minimum variabel Dukungan Keluarga adalah 92 dan batas maksimumnya adalah 135, dengan range 43. Untuk membagi menjadi tiga kelas interval yaitu rendah, sedang dan tinggi, dapat dilakukan dengan cara membagi range $\left(\sum \mathrm{k}\right)$ menjadi tiga bagian, yaitu 43:3 = 14,3, yang dibulatkan menjadi 14 .

Sedangkan variabel Keterlibatan Melayani ada pada batas minimum 73 dan maksimum 110, dengan range 37. Dengan demikian range untuk kelas interval adalah: $37: 3=12,3$, dan dibulatkan menjadi 12. Sementara itu nilai lowwer-upper bound ada pada digambarkan pada tabel berikut:

One-Sample Test

\begin{tabular}{|c|c|c|c|c|c|c|}
\hline \multicolumn{7}{|c|}{ Test Value $=0107,64-116,93$} \\
\hline & $\mathrm{T}$ & $\mathrm{df}$ & $\begin{array}{c}\text { Sig. (2- } \\
\text { tailed) }\end{array}$ & $\begin{array}{c}\text { Mean } \\
\text { Difference }\end{array}$ & $\begin{array}{c}\text { 95\% Confidence Interval } \\
\text { of the Difference }\end{array}$ \\
\cline { 5 - 7 } & & & Lower & Upper \\
\hline $\begin{array}{c}\text { Dukungan } \\
\text { Keluarga }\end{array}$ & 49.086 & 34 & .000 & 112.286 & 107.64 & 116.93 \\
\hline $\begin{array}{c}\text { Keterlibatan } \\
\text { Melayani }\end{array}$ & 51.745 & 34 & .000 & 92.571 & 88.94 & 96.21 \\
\hline
\end{tabular}

Kelas interval variabel Dukungan Keluarga ditunjukkan tabel di bawah ini: 


\begin{tabular}{|c|c|c|}
\hline Kelas Interval & Keterangan kelas & Nilai Lower-Upper Bound \\
\hline $92-106$ & Rendah & \\
\hline $107-121$ & Sedang & $107.64-116.93$ \\
\hline $122-135$ & Tinggi & \\
\hline
\end{tabular}

Artinya nilai Lower-Upper Bound variabel Dukungan Keluarga 107,64 - 116,93 tersebut ada pada kategori sedang. Hal ini berarti bahwa dukungan keluarga kepada jemaat lansia untuk melayani ada pada kategori sedang.

Sementara untuk variabel Keterlibatan Melayani ditunjukkan pada tabel kelas interval berikut:

\begin{tabular}{|c|c|c|}
\hline Kelas Interval & Keterangan kelas & Nilai Lower-Upper Bound \\
\hline $73-85$ & Rendah & \\
\hline $86-98$ & Sedang & $88.94-96.21$ \\
\hline $99-110$ & Tinggi & \\
\hline
\end{tabular}

Nilai Lower-Upper Bound variabel keterlibatan melayani jemaat lansia ada pada kategori sedang. Artinya, keterlibatan jemaat lansia dalam melayani di Gereja Bethel Injil Sepenuh Kepunton Surakarta adalah sedang.

Untuk mengetahui besarnya korelasi kedua variabel, maka penulis menggunakan analisis korelasi Pearson Product Moment dengan bantuan SPSS 17.0, dan didapatkan hasilnya dalam tabel di bawah ini:

\begin{tabular}{|c|c|c|c|}
\hline \multirow{2}{*}{} & & $\begin{array}{c}\text { Cukungan } \\
\text { Keluarga }\end{array}$ & $\begin{array}{c}\text { Keterlibatan } \\
\text { Lansia Melayani }\end{array}$ \\
\hline \multirow{2}{*}{\begin{tabular}{c} 
Dukungan Keluarga \\
\cline { 2 - 4 }
\end{tabular}} & Pearson Correlation & 1 & $.461^{* *}$ \\
\cline { 2 - 4 } $\begin{array}{c}\text { Keterlibatan Lansia } \\
\text { Melayani }\end{array}$ & Pearson Correlation & $.461^{* *}$ & .005 \\
\cline { 2 - 4 } & Sig. (2-tailed) & .005 & 35 \\
\cline { 2 - 4 } & $\mathrm{N}$ & 35 & 35 \\
\hline
\end{tabular}

**. Correlation is significant at the 0.01 level (2-tailed).

Sesuai dengan tabel di atas, ditemukan $\mathrm{r}_{\mathrm{xy}}$ sebesar 0,461dan bernilai positif. Tingkat korelasi kedua variabel dapat dilihat dalam tabel interprestasi koefisien korelasi nilai $r$ di bawah ini: 


\begin{tabular}{|c|c|c|}
\hline Interval Koefisien & $\begin{array}{c}\text { Tingkat } \\
\text { Hubungan/Pengaruh }\end{array}$ & $\begin{array}{c}\text { Nilai } \\
\text { korelasi }\end{array}$ \\
\hline $0.800-1.000$ & Sangat Kuat & \\
\hline $0.600-0.799$ & Kuat & \\
\hline $0.400-0.599$ & Sedang & 0,461 \\
\hline $0.200-0.399$ & Lemah & \\
\hline $0.000-0.199$ & Sangat Lemah & \\
\hline
\end{tabular}

Hasil tersebut memperlihatkan bahwa pengaruh dukungan keluarga terhadap keterlibatan jemaat lansia dalam melayani di Gereja Bethel Injil Sepenuh Kepunton Surakarta ada pada kategori sedang. Temuan ini sekaligus mengimplikasikan kegiatan untuk meningkatkan dukungan keluarga dan keterlibatan jemaat lansia dalam melayani. Gereja harus melakukan berbagai cara, di antaranya memberikan motivasi, baik lewat khotbah di mimbar maupun komunikasi secara pribadi kepada setiap keluarga yang memiliki anggota keluarga yang lanjut usia agar memberikan dorongan anggota keluarga lansia untuk terlibat melayani.

\section{Keterlibatan Lansia dalam Pelayanan}

Setiap gereja memiliki cara dan gaya tersendiri dalam memberdayakan umatnya. Pemberdayaan tersebut memiliki tujuan dengan kebijakan masing-masing, yang sudah tentu berlandaskan pada nafas firman Tuhan. Dengan melibatkan jemaat yang telah memasuki usia lanjut, diharapkan mereka dapat memenuhi peranannya dalam tanggung jawab yang dipercayakan.

Pertama, jemaat lanjut usia dapat mengisi keputusasaan pada usia ini dengan melibatkan diri dalam kegiatan gereja seperti bergabung dalam pelayanan pendoa syafaat, penasihat, perencana program dan keteladanan bagi generasi penerus (Titus 2:1-5). " Orang-orang tua tidak perlu menjadi kelompok yang besuasana kelabu, tanpa suara...Sebetulnya dalam diri para orang tua kita akan lebih dapat menemukan berbagai kekhususan dan keistimewaan serta kemampuan-kemampuan tertentu kalau dibandingkan dengan yang dapat kita temukan dalam diri orang-orang muda" Keterlibatan melayani merupakan bentuk pemanfaatan positif dari waktu yang tersisa (Maz. 90:1-12; Ef. 5:16-17; Kol. 4:6).

Kedua, penurunan dan perubahan fisiologis serta psikologis memberi kesan masa ini seseorang kembali kekanak-kanakan. Jemaat yang telah memasuki usia lanjut

${ }^{11}$ Henry J.M.Nouwen dan Walter J.Gaffney, Meniti Roda Kehidupan - Tambah Usia Menuju Kepenuhan Hidup (Yogyakarta: Penerbit Kanisius, 1997), 41 
dapat dibina lebih awal untuk bisa memahami keadaan mereka serta memberikan dukungan yang berarti.

Ketiga, jemaat lansia dapat dimotivasi dalam relasinya yang lebih bersifat pribadi kepada Tuhan (Maz. 71:1-24) . "Hendaknya jangan dilupakan bahwa dalam usaha mempersiapkan diri menghadapi masa usia lanjut, agama yang dianut seseorang memegang peranan penting" 12 , dalam hal ini agama bukan hanya sekedar suatu kepercayaan yang dimiliki seseorang namun pengertian yang lebih mendalam adalah seseorang yang telah lanjut usia membutuhkan hubungan yang khusus dan pribadi bersama dengan Tuhan. Kedekatan dan pengenalan seorang yang telah lanjut usia kepada Tuhan juga akan membantu untuk memperapkan mereka menghadapi kematian dengan meyakinkan adanya jaminan keselamatan di dalam Tuhan melalui Yesus(II Kor. 4:16-10; I Tes. 4:13-18).

Keempat, masa lanjut usia adalah suatu masa di mana kebanyakan seseorang mulai mengalami kehilangan karena kematian pasangan hidup, saudara ataupun temanteman.

Bagi banyak orang menghadapi usia lanjut berarti menghadapi kesepian. Bagi janda dan duda, ketakutan dan kesadaran akan kesendirian, sering menjadi pengalaman yang menakutkan dan menekan. Banyak orang lanjut usia - baik laki-laki maupun perempuan mengakui bahwa penderitaannya yang paling berat adalah rasa kesepian. Teman-teman dekat satu persatu meninggal dunia. ${ }^{13}$

Di sisi yang lain, dalam tahap ini, kemunduran secara fisiologis membuat seorang yang telah memasuki lanjut usia tidak lagi dapat beraktifitas seperti pada waktu masih muda. Dalam fase ini, seseorang yang telah memasuki masa lanjut usia mulai mengalami perasaan kesepian dan merasa tidak berguna. Tekanan-tekanan psikologis ini akan cukup berbahaya apabila terus dibiarkan, sebab akan berujung kepada kondisi depresi, putus asa dan akibatnya kehilangan semangat hidup. Keaktifan jemaat lanjut usia dalam ibadah dan pelayanan di gereja akan banyak membantu mereka untuk menemukan keberhargaan diri karena peranan-peranan yang mereka lakukan didalam gereja, selain dari itu mereka juga menemukan komunitas yang akan membuat mereka tidak lagi merasa kesepian dan tidak berharga. Dengan demikian, gereja telah turut mengambil bagian dalam fungsi perhatian dan perawatan bagi jemaat lanjut usia.

\footnotetext{
${ }^{12}$ R.E.M.Suling dan S.S. Pelenkahu, Pedoman Praktis Bagi Manusia Usia Lanjut. (Jakarta : BPK Gunung Mulia, 1996), 59

${ }^{13}$ Alfons Deeken, Usia Lanjut (Yogyakarta: Penerbit Kanisius, 1997), 33
} 


\section{Keterlibatan Lansia dalam Melayani di GBIS Kepunton Surakarta}

Sekalipun telah memasuki usia lanjut, bukan berarti bahwa jemaat lansia tidak dapat ikut berperan dalam kegiatan dan pelayanan dalam gereja. Karunia-karunia Roh Kudus diberikan kepada semua orang percaya tanpa memandang usia, dengan demikian jemaat lanjut usia adalah kelompok yang tidak dapat diabaikan begitu saja. Sesuai dengan karunia yang Tuhan berikan dalam hidup mereka, maka mereka dapat berperan aktif dan menjadi berkat dimana mereka ditempatkan. Di Gereja Bethel Injil Sepenuh Kepunton para lansia menangani beberapa bidang pelayanan seperti:

\section{Berperan aktif dalam Komisi Lanjut Usia}

Komisi lanjut usia dalam gereja dapat menjadi wadah yang efektif untuk jemaat lanjut usia dapat bersosialisasi, menemukan teman-teman seusia, mengadakan kegiatankegiatan bersama yang sesuai dengan usia mereka dan aktif terlibat dalam pelayanan didalamnya. Selain dari itu, dalam ibadah komisi Lanjut Usia, penyampaian Firman Tuhan berhubungan dengan persoalan lanjut usia, pemberian motivasi serta semangat, penghiburan dari sisi krisis lanjut usia menjadi materi-materi Firman Tuhan yang disampaikan, selain dari bulan-bulan tertentu pengurus ibadah mengadakan acara-acara khusus seperti bincang lansia, menyampaikan materi kesehatan untuk lanjut usia ataupun bentuk-bentuk acara pengakraban.

Mendengar Firman Tuhan secara khusus bagi usia kelompok ini sangat efektif mengingat krisis dan tekanan secara phsicologis banyak dihadapi jemaat dalam masa dewasa lanjut tersebut. Itu sebabnya bobot materi Firman Tuhan yang disampaikan dalam ibadah juga perlu diperhatikan dan dicermati supaya "makanan"rohani yang diberikan menjadi tepat sasaran dan tepat guna.

Gereja Bethel Injil Sepenuh Kepunton dalam tahun 2015 baru memiliki satu kali ibadah lanjut usia dalam setiap bulan. Dengan jumlah anggota mencapai 156 orang dan jumlah kehadiran aktif setiap ibadah 120-140 orang. Ibadah lanjut usia ini dinamai Ibadah 464, yang diambil dari Yesaya 46:4 tentang janji pemeliharaan Tuhan hingga masa putih rambut kepada umatNya. Komisi ini sangat efektif sebab dari mula pertama diadakan seluruh pelayan Tuhan yang melayani dalam ibadah dan pengurus komisi, hampir 97\% adalah jemaat yang telah berusia lanjut usia.

\section{Berperan dalam pelayanan Firman Tuhan}

Jemaat lanjut usia secara efektif dapat memberikan sumbangan kepada pelayanan di komisi-komisi yang lain melalui pelayanan mimbar yang berupa 
memimpin pujian, mendukung doa, bersaksi di mimbar ataupun menyampaikan Firman Tuhan. Di dalam Gereja Bethel Injil Sepenuh Kepunton, selain dari jemaat lanjut usia memiliki wadah di Ibadah 464, mereka juga dapat melayani di ibadah-ibadah lain seperti di Ibadah keluarga yang diadakan di rumah-rumah jemaat, ataupun ibadah Pemahaman Alkitab, Ibadah Sekolah Minggu di kelas besar dimana range usia kelas besar 12-17 tahun ataupun di Ibadah Wanita. Selain itu beberapa diantara mereka juga terjadwal dalam penyampaian renungan singkat di siaran radio Tifara On Air yang menginduk di Radio Immnuel, dengan menyisipkan jam-jam renungan Firman Tuhan pada setiap hari Rabu pukul 19:30 WIB dan hari Sabtu pukul 19:00 WIB.

\section{Persekutuan rumah tangga}

Gereja memiliki persekutuan-persekutuan rumah tangga yang biasanya diadakan dirumah-rumah jemaat secara berkeliling/bergantian. Persekutuan Rumah Tangga menjadi tempat yang juga tepat bagi jemaat lanjut usia yang ingin terjun dalam pelayanan. Dalam persekutuan rumah tangga ini, jemaat lansia dapat mengambil peranan untuk terlibat didalamnya dalam bentuk pelayanan langsung dalam persekutuan, memimpin pujian, menyampaikan renungan Firman Tuhan, bersaksi, memimpin doa ataupun mengijinkan dipakainya rumah mereka untuk menjadi tempat bagi umat Tuhan berkumpul.

\section{Pendukung Doa}

Pelayanan ini adalah pelayanan yang dapat dengan mudah diikuti oleh jemaat yang telah memasuki usia lanjut. Kebanyakan wadah pendukung doa dipenuhi dengan jemaat yang telah lanjut usia kartena pelayanan ini tidak memerlukan kegiatan fisik terlalu banyak. Dalam Gereja Bethel Injil Sepenuh Kepunton, ada beberapa pelayanan doa yang kebanyakan anggotanya adalah jemaat lanjut usia. Pelayanan-pelayanan yang dapat dikerjakan adalah Pelayanan Pendukung Doa dalam Ibadah Umum yang melaksanakan pelayanan setiap hari Minggu bersamaan dengan jam Ibadah umum dilaksanakan, pelayanan Komando (Komunitas Umat Tuhan Berdoa) dengan jadwal doa setiap hari Kamis pukul 19.00 WIB dan pelayanan Doa malam yang diadakan setiap Selasa ke II pukul 19.00 WIB.

\section{Bergabung dalam Tim Besuk Jemaat}

Beberapa jemaat lanjut usia yang sudah tidak bekerja memiliki lebih banyak waktu luang, mereka dapat turut bergabung dalam pelayanan pembesukan di rumah- 
rumah jemaat. Dalam beberapa hal, karena orang-orang lanjut usia lebih memiliki banyak pengalaman hidup maka kesaksian-kesaksian hidup mereka kepada jemaat yang dibesuk akan menjadi jauh lebih efektif.

Tim besuk jemaat di Gereja Bethel Injil Sepenuh Kepunton disebut dengan Tim Pelayanan Jangkar. Tim pelayanan ini memiliki jadwal yang rutin setiap hari Jumat untuk mengadakan pembesukan bagi jemaat yang memerlukan kunjungan khusus seperti, jemaat yang menderita sakit, jemaat yang telah lama tidak hadir dalam ibadah atau jemaat yang memiliki persoalan-persoalan.

\section{Pelayanan Rumah Sakit}

Wadah pelayanan ini biasanya dalam bentuk tim-tim bezuk yang sudah tetap. Dalam pelayanan ini, mereka dapat mendoakan dan menghibur orang-orang sakit yang dibezuk. Kunjungan dan sapaan kasih yang mereka berikan kepada orang sakit juga dapat berakibat kepada munculnya rasa percaya diri dan keberhargaan bagi pelayanpelayan yang telah berusia lanjut tersebut.

Di Gereja Bethel Injil Sepenuh Kepunton tim pelayanan rumah sakit disebut dengan Tim Bethesda. Bekerjasama dengan beberapa Rumah Sakit di Surakarta, setiap hari Kamis dan Jumat secara rutin mereka mengadakan pelayanan pelayanan khusus di beberapa Rumah Sakit. Adapun Rumah Sakit yang telah bekerjasama dengan Gereja Bethel Injil Sepenuh Kepunton adalah : Rumah Sakit dr.Oen Kandang Sapi dan Rumah Sakit Brayat Minulya.

\section{Mengajar Sekolah Minggu}

Pelayanan Sekolah Minggu adalah salah satu bentuk pelayanan yang tidak memiliki batasan usia. Dalam pelayanan ini, jemaat lanjut usia dapat mengambil peranan sebagai pengajar untuk menyampaikan Firman Tuhan, memimpin pujian ataupun menjadi seksi pemerhati bagi anak-anak yang dilayani. Dengan jumlah 24 kelas yang terbagi dalam 13 level sesuai dengan usia anak, maka guru-guru Sekolah Minggu yang telah memasuki lanjut usia dapat memilih kelas yang paling tepat untuk mereka dapat mengajar. Biasanya mereka lebih menyukai untuk mengajar di kelas Balita karena aktifitas anak yang cenderung tidak terlalu banyak atau justru di kelas pra remaja dimana penyampain Firman Tuhan sudah dalam bentuk renungan. 


\section{Paduan Suara}

Pelayanan Paduan Suara juga dapat menjadi sebuah wadah yang tepat bagi jemaat lanjut usia. Biasanya dalam kelompok Paduan Suara ini juga akan disesuaikan dengan usia rata-rata dari anggotanya. Selain dari pada itu jenis pemilihan lagunyapun akan disesuaikan dengan usia mereka. Tidak jarang bagi jemaat lanjut usia yang dapat memainkan alat music, mereka dapat ikut berperan dengan memainkan alat music pengiring paduan suara tersebut.

Pelayanan Paduan Suara di Gereja Bethel Injil Sepenuh Kepunton terbagi jadi beberapa bagian, Paduan Suara Umum yang melayani dalam Ibadah hari Minggu pukul 09.00 WIB, dengan syarat telah masuk dalam babtisan dan usia minimal anggota paduan suara adalah 13 th, Paduan Suara Bapak Ibu, Paduan Suara Persekutuan 464. Pelayanan-pelayanan paduan suara tersebut dapat diikuti oleh jemaat yang telah berusia lanjut.

\section{Siaran Radio}

Bentuk pelayanan yang juga dapat melibatkan jemaat lanjut usia adalah pelayanan radio, dimana jemaat memiliki kesempatan untuk dapat mengisi program acara yang berupa penyampaian renungan Firman Tuhan, kesaksian ataupun programprogram yang lain yang sesuai dengan kemampuan dan kapasitas mereka.

Pelayanan radio di Gereja Bethel Injil Sepenuh Kepunton dimulai sejak bulan September 2008. Bekerjasama dengan radio Immanuel Solo yang mengudara pada frekwensi 94,3 FM, siaran ini juga bisa diakses secara internasional melalui media internet dengan cara streaming melalui website $w w w$.jogjastreamers.com. Program yang dibawakan dalam pelayanan penyiaran Gereja Bethel Injil Sepenuh Kepunton disebut dengan program Tifara On Air dengan beberapa jam siar yang dapat melibatkan jemaat lansia untuk dapat ikut berperan serta melayani. Jam siar yang memungkinkan untuk jemaat lanjut usia melayani adalah sebagai berikut: Hari Rabu dan Sabtu pukul 19:00 19:30 WIB dalam bentuk pelayanan Firman Tuhan dan pada setiap hari Jumat sebelum diadakannya ibadah Lanjut Usia yang diadakan sebulan sekali pada hari Sabtu pertama, dengan program Sapaan Usia Indah, sebuah acara yang dikemas khusus dari dan untuk pendengar lanjut usia dan khususnya jemaat lanjut usia di Gereja Bethel Injil Sepenuh Kepunton. 


\section{Penerima Tamu}

Pelayanan penerima tamu atau penyambut jemaat datang dalam ibadah adalah pelayanan yang sederhana, namun memiliki peranan yang besar untuk membuat jemaat menjadi nyaman karena diterima dan disambut baik sebelum mereka masuk dalam ruang ibadah. Pelayanan penerima tamu ini sangat sederhana dan jemaat lansia dapat turut ambil bagian didalamnya. Pengaruh positif dapat dirasakan dari dua sisi, dari pihak jemaat yang hadir akan diberkati karena melihat semangat para orang tua yang mau melayani sementara bagi jemaat lansia yang melayani dapat merasakan keberhargaan dan suka cita karena dapat berinteraksi dengan banyak orang.

Pelayanan penerima tamu di Gereja Bethel Injil Sepenuh Kepunton melibatkan 8 orang dalam setiap ibadahnya. Dengan Ibadah umum yang diadakan tiga kali dalam satu minggu, maka beberapa jemaat lanjut usia dapat turut berperan serta melalui pelayanan yang sederhana ini.

\section{Kesimpulan}

Kesimpulan dalam penelitian ini adalah: Dukungan keluarga terhadap keterlibatan jemaat lanjut usia (lansia) Gereja Bethel Injil Sepenuh Kepunton Surakarta dalam melayani ada pada kategori sedang. Hal ini dipengaruhi oleh karena dukungan keluarga yang sedang sehingga pengaruhnya terhadap keterlibatan mereka untuk melayani juga sedang.

\section{Rekomendasi}

Bagian ini lebih kepada upaya-upaya yang direkomendasikan oleh penulis untuk meningkatkan dukungan keluarga terhadap anggota keluarga yang lansia untuk terlibat dalam pelayanan di Gereja Bethel Injil Sepenuh Kepunton Surakarta. Beberapa hal dapat dilakukan seperti:

\section{Seminar Keluarga}

Pelaksanaan Seminar Keluarga dengan pembahasan khusus tentang Lansia. Acara ini lebih tepat diprogramkan pada hari libur, dengan harapan bahwa melalui seminar maka jemaat akan dibukakan wawasannya sehubungan dengan kondisi-kondisi yang dihadapi oleh jemaat yang telah lanjut usia. Bahasan yang meliputi persoalanpersoalan lanjut usia, tugas-tugas perkembangannya, pergumulan dan hambatan orangorang yang lanjut usia serta peranan lansia dalam gereja, akan menolong bagi jemaat khususnya keluarga-keluarga yang memiliki anggota keluarga yang telah memasuki lanjut usia ataupun bagi jemaat lansia sendiri untuk dapat memahami keberadaannya 
dan menyikapi semua kelemahan dan kesulitan yang harus dihadapi dengan terang Firman Tuhan.

\section{Kotbah Khusus tentang Dukungan Keluarga di Ibadah Umum}

Diusulkannya kepada gembala sidang untuk menyampaikan materi kotbah yang khusus berhubungan dengan pentingnya dukungan keluarga terhadap anggota keluarga lansia untuk melayani. Penyampaian Firman Tuhan ini dapat diberikan kepada jemaat pada jam-jam ibadah khusus dimana jemaat yang hadir mayoritas adalah keluarga. Di dalam Gereja Bethel Injil Sepenuh Kepunton Surakarta, jadwal ibadah ke dua yang diadakan pada pukul 09.00 WIB, lebih banyak dihadiri oleh keluarga-keluarga dibanding dengan ibadah pertama yang mayoritas kehadiran adalah orang-orang tua dan ibadah ke tiga yang mayoritas adalah anak-anak muda. Pemilihan jam ibadah yang tepat untuk penyampaian materi ini sangat penting supaya apa yang menjadi sasaran, yaitu mendorong keluarga-keluarga untuk mendukung anggota keluarganya yang lansia supaya aktif dalam pelayanan, dapat tercapai.

\section{Retreat Khusus bagi Jemaat Lanjut Usia}

Retreat bagi jemaat lansia berperan banyak untuk mereka dapat mengembangkan hidup bersosial, mengatasi kesepian dan memberikan kegiatan yang bermanfaat bagi kerohanian. Beberapa hal yang tidak dapat diabaikan dalam persiapan retreat bagi jemaat lansia adalah : persiapan panita yang melibatkan orang-orang muda, pemilihan tempat retreat yang sesuai untuk lansia, syarat peserta, tema-tema Session dan KKR yang sesuai, pembicara yang tepat dan persiapan konsumsi.

Pelaksanaan retreat lansia harus juga melibatkan orang-orang muda sebagai pelaksana lapangan. Dalam pelaksanaan retreat yang bisa saja diadakan dua hari satu malam, ataupun tiga hari dua malam, orang-orang muda harus dipersiapkan untuk menolong peserta lansia yang membutuhkan bantuan, baik dalam hal bantuan langsung dengan membawakan tas-tas perlengkapan mereka sampai ke dalam kamar, menolong dalam melayani di meja makan, mengingatkan untuk jam-jam acara sampai kepada pelaksanaan acara yang membutuhkan perlengkapan-perlengkapan dan aktifitas dari orang-orang muda yang lebih gesit untuk bergerak.

Pelaksanaan retreat juga tidak dapat mengabaikan pertimbangan lokasi tempat dan kondisi ruangan-ruangannya. Kebanyakan lokasi retreat ada ditempat yang berdaerah gunung, sehingga dalam area tempat tersebut banyak tangga yang harus dilewati. Hal ini menjadi pertimbangan penting sehubungan dengan gerak aktifitas 
lansia yang kebanyakan cukup kesulitan jika harus menaiki tangga-tangga. Demikian juga pemilihan lokasi yang juga harus mempertimbangkan jarak kamar tidur ke kamar mandi, perlu untuk dipertimbangkan lokasi yang lebih aman sehingga terhindar dari kecelakaan karena terpeleset. Ataupun jarak menuju aula atau ruang makan, yang tidak terlalu jauh.

Peserta retreat lansia juga perlu diperhatikan oleh panitia. Hal ini berhubungan dengan syarat-syarat peserta, dimana perlu dipertimbangkan kondisi kesehatan dan kemandirian lansia dalam beraktifitas. Apabila keadaan calon peserta tidak begitu sehat, panitia perlu untuk memberikan pertimbangan supaya peserta menunda dulu keikutsertaannya. Terkadang ada beberapa lansia yang memutuskan untuk mengikuti dengan membawa pendamping, baik itu anak, cucu, pembantu ataupun suster. Dalam hal ini bantuan-bantuan tersebut akan meringankan pekerjaan panitia.

Selain dari persiapan secara tehnis, pengadaan lansia retreat juga perlu mempertimbangkan tema-tema dalam session dan KKR yang lebih tepat dan memenuhi kebutuhan para lansia. Pelaksanaan retreat menjadi salah satu kesempatan bagi gereja untuk memotivasi mereka yang telah memasuki lanjut usia supaya terbeban dalam melayani digereja sekalipun telah lanjut usia. Pembicara yang tepat dengan materimateri yang membahas persoalan orang-orang lanjut usia dalam Alkitab, pandangan Tuhan terhadap orang-orang lanjut usia, keberhargaan manusia dalam segala usia dihadapan Tuhan serta materi-materi yang berhubungan dengan kesehatan lansia dimasa tua, akan menjadi pembahasan yang sangat bermanfaat dan memotifasi mereka untuk hidup sehat dan bersemangat dalam pekerjaan Tuhan.

Dan hal yang lain yang juga tak dapat diabaikan adalah perhatian dari panitia khususnya bagian konsumsi untuk mempersiapkan menu-menu makan pagi, makan siang ataupun makan sore, dengan penyusunan menu yang sehat dan tidak memicu penyakit-penyakit tertentu yang sering muncul pada kelompok orang-orang lanjut usia. Tentu juga panitia perlu mempersiapkan seksi kesehatan, atau bila perlu mengikut sertakan jemaat yang memiliki profesi sebagai dokter, untuk terlibat dalam pelaksanaan retreat lansia tersebut.

\section{Referensi}

Deeken, Alfons, Usia Lanjut, Yogyakarta: Penerbit Kanisius, 1997

Efendy, Ferry dan Makhfudli. Keperawatan Kesehatan Komunitas: Teori dan Praktik dalam Keperawatan, Jakarta: Salemba Medika, 2009

Ihromi, T.O. Bunga Rampai Sosiologi Keluarga, Jakarta: Yayasan Obor, 1999 
Nouwen, Henry J.M. dan Gaffney, Walter J. Meniti Roda Kehidupan - Tambah Usia Menuju Kepenuhan Hidup, Yogyakarta: Penerbit Kanisius, 1997

Suling, R.E.M. dan Pelenkahu, S.S. Pedoman Praktis Bagi Manusia Usia Lanjut. Jakarta : BPK Gunung Mulia, 1996

UU No.10 tahun 1992 jo PP No.21 tahun 1994

http://griyaamerta-malang.blogspot.co.id/2014/12/dukungan-keluarga.html. Diunduh 24 Mei 2016; 20:25 WIB.

SABDA, CD-ROM 